Pääkirjoitus

\title{
Mitä vuorovaikutuksesta pitäisi tutkia seuraavaksi?
}

Puheviestinnän vuosikirja Prologi julkaisee ihmisten väliseen vuorovaikutukseen liittyväă tuoreinta tutkimusta. Prologissa julkaistaan puheviestintätieteellisen tutkimuksen lisäksi monitieteistä vuorovaikutuksen tutkimusta ja kirjoittajia kannustetaan teksteissä vuoropuheluun puheviestinnän alalla tehdyn tutkimuksen kanssa. Täten Prologi pyrkii lisäämään yhteistyötä eri alojen asiantuntijoiden kanssa. Minulla on ollut kunnia toimia lehden päätoimittajana vuosina 2017-2018. Tieteellisen lehden toimittaminen yhdessä asiantuntevan toimituskunnan kanssa on ollut antoisaa ja mieluisaa työtä. Vuosien aikana olen saanut lukea useit mielenkiintoisia tutkimusartikkeleita, joista tämän vuoden numeroon päätyi julkaistaviks neljä. Päätoimittajan kauteni lopussa mieleen herää kysymys, mitä vuorovaikutuksesta pitäis tutkia seuraavaksi? Käsittelen aihetta neljännen teollisen vallankumouksen näkökulmasta kahden esimerkin avulla.

Elämme tällä hetkellä neljättä teollista vallan kumousta, mihin yhdistetään muun muassa digitalisaatio, robotismi, pitkälle edennyt automatisoituminen ja tekoäly (Syam \& Sharma 2018). Kukaan ei vielä tiedä, mihin kaikkeen neljäs teollinen vallankumous lopulta johtaa mutta se tiedetään, että maailma muuttuu jat- kuvasti ja pysyvästi. Muutokseen sisältyy aina sekä uhkia että mahdollisuuksia, jotka molemmat on hyvä tiedostaa. Keskityn tässä pääkirjoituksessa muutoksen tuomiin mahdollisuuksiin, joihin vuorovaikutuksen tutkijat voivat tarttua jatkuvasti kehittyvän yhteiskunnan, elinkeinoelämän ja työelämän tutkimisen kautta. Mahdollisuuksia on lukuisia, mutta olen rajannut arkastelun puheviestinnän opetukseen, opetusviestintään sekä liiketoimintaan.

Otan ensimmäisen esimerkin puheviestinnän opetuksen ja opetusviestinnän tutkimuksesta. Edwards ja Edwards (2017) esittävät, että tekoäly, sosiaaliset robotit ja virtuaalimaailmat ovat kolme tärkeintä tulevaisuuden tutkimuksen kohdetta opetusviestinnän alueella. Tällä hetkellä tekoälyyn perustuvia tietokoneohjelmia ja sosiaalisia robotteja käytetään opettajina, opettajien apuna, tuutoreina ja vertaisopettajina ympäri maailmaa (Atkinson 2018; Edwards ym. 2018). On ennustettu, että koneet (machine agents) korvaavat opettajia pikku hiljaa seuraavien kymmenen vuoden aikana, koska ne pystyvät mukauttamaan viestintäänsä opiskelijoiden yksilöllisiin tarpeisiin, tietotasoon ja oppimistyyleihin perustuen (Bodkin 2017; Edwards ym. 2018). Suomessa puheviestinnän opettajat toteuttavat erilaisia verkkokursseja, etäopetusta, monimuoto-opetusta ja flipattua opetusta (flipped classroom). Flipatun opetuksen eli käänteisopetuksen mallissa opiskelija perehtyvät ensin ennakkomateriaaleihin, kuten videoluentoihin, artikkeleihin tai vaikkapa podcasteihin, ja tekevät ennakkotehtäviä ennen saapumistaan lähiopetukseen. Lähiopetus ei perustu opettajan luennointiin, vaan tietojen ja taitojen syventämiseen erilaisten yhteistoiminnallisten tehtävien, ryhmäkeskustelujen ja harjoitusten avulla. (Chen, Wang \& Chen 2014.) Jo nyt hyödynnämme puheviestinnän opetuksess runsaasti erilaisia teknologisia sovelluksia, tietokoneohjelmia ja teemme esimerkiksi videoituja mini-luentoja verkkoon, joita opiskelija voivat katsoa ennen ryhmätapaamiseen saapumista. Näistä puheviestinnän opetuskokeiluista olisi kiinnostavaa lukea myös tieteellisiä julkaisuja, sillä opetusviestinnän tutkijat eivät ole juurikaan tutkineet flipattua puheviestinnän opetusta (Valenzano \& Wallace 2017), vaikk siitä löytyy runsaasti tutkittua tietoa muilta tieteenaloilta (ks. Chen ym. 2014; Tusa ym. 2018) ja esimerkiksi organisaatio- ja markkinointiviestinnän alueelta (Kantanen ym. 2018). Seuraavat kysymykset voisivat olla kiinnostavia tutkimuksen näkökulmasta:
Kuinka flipatut puheviestinnän kurssit onnistuvat ja millaisia oppimistuloksia niillä saavutetaan?

Millaisia vuorovaikutukseen, itseohjautuvuuteen tai opettajan ja opiskelijoiden rooliin liittyviä erityiskysymyksiä flippaukseen liittyy?

Millaisilla oppimisympäristöillä edistämme parhaiten teknologiaan tottuneiden z-sukupolven edustajien vuorovaikutusosaamisen kehittymistä?

Entä milloin ja miten sosiaaliset robotit tulevat avuksi suomalaiseen puheviestinnän opetukseen? Sosiaalisia robotteja (social robot) sekä etäyhteyden avulla käytettäviä robotteja (telepresence robots) on jo käytetty menestyksekkäästi luentomuotoisessa opetuksessa viestinnän peruskurssilla Yhdysvalloissa (Edwards ym. 2016). Opiskelijat kokivat molemmat edellä mainitut robotit vakuuttavina luennoitsijoina ja raportoivat myös affektiivisia ja behavioraalisia oppimistuloksia (Edwards ym. 2016). Monia tutkimusaukkoja kuitenkin vielä löytyy, kun pohdimme kuinka robotti pystyy opettamaan ihmisten väliseen vuorovaikutukseen liittyviä monimutkaisia asioita. Esimerkiksi Edwards ja Edwards (2017) kysyvät, kuinka opetusviestintä toteutuu ja toimivatko samanlaiset opetus- ja 
oppimisstrategiat kasvokkaisessa opetustilan teessa kuin ihmisen ja robotin välisessä vuorovaikutuksessa? Edwards ja kollegat (2018) poh tivat, muuttuuko opettajan rooli työnjohtajaksi, joka suunnittelee ja valitsee koneen toteuttaman opetuksen sisällöt, valvoo opiskelijoiden edistymistä ja tarjoaa sosiaalista tukea? Lisäks tutkimuksen näkökulmasta kiinnostavia kysymyksiä voisivat olla esimerkiksi seuraavat:

- Kuinka sosiaalinen robotti pystyy antamaan palautetta puheviestinnän taitoharjoituksista, jos siihen ohjelmoidaan oikean opettajan toimintamallit, luentomuistiinpanot, palautteenantotavat sekä erilaisten oppijoiden oppimistyylit ja viestijäprofiilit?

- Kuinka sosiaalinen robotti pystyy kohtaamaan opiskelijoiden erilaiset tunnereaktiot ja vastaamaan niihin?

Millaisia eettisiä, sosiaalisia ja yksityisyyteen liittyviä kysymyksiä on ratkaistava, kun robotit siirtyvät apuopettajiksi, tukiopettajiksi tai opettajiksi?

Kuinka vuorovaikutus opetuskontekstissa muuttuu, kun se tapahtuu ihmisen ja koneen välillä?

- Kuinka puheviestinnän opettajat ylipäänsä asennoituvat tällaiseen muutokseen?

Lisää ideoita opetusviestinnän tulevaisuuden tutkimusaiheista löytyy Communication Education -lehden foorumilta, jossa lukuisat tutkijat visioivat opetusviestinnän tulevaisuuden tutkimustarpeita (Hess \& Mazer 2017).

Otan toisen esimerkin liiketoiminnan alueelta. Kun automatisoituminen ja robotiikka yleistyvät, on yhä todennäköisempää että kuluttajina teemme ostoksemme verkkokaupasta (Arli, Bauer \& Palmatier 2018). Big dataan perustuen meille ilmoitetaan tuotteista, joita emme olisi itse edes ajatelleet tarvitsevamme, mutta jotka saattaisivat meitä kiinnostaa. Mieltämme askarruttavissa kysymyksissä meitä opastaa ihmisen sijaan chatbot (Hill, Ford \& Farreras 2015). Chatbot on tietokoneohjelma, joka pystyy keskustelemaan ihmisen kanssa toistamalla siihen etukäteen syötettyjä viestejä. Osa chatboteista sisältää tekoälyä, jolloin ne myös oppivat käyttäytymismalleja. (Hill ym. 2015.) Tutkimukset osoittavat, että varsinkin B2C (business-to-consumer) kaupassa chatbottien käyttäminen on tuloksellista ja ihmiset keskustelevat mielellään chatbotin kanssa (Hill ym. 2015). Olisi kiinnostavaa tietää, kuinka monimutkaisiin päätelykykyä ja ongelmanratkaisutaitoa vaativiin tehtäviin, joita tarvitaan erityisesti yritysten välisessä (business-to-business) kaupassa, chatbot tulevaisuudessa pystyy. Pystyykö chatbot tarjoamaan todella räätälöityjä monimutkaisia rat- kaisuja ja luomaan samalla hyväksi arvioidun ja luottamusta herättävän ammatillisen suhteen asiakkaan kanssa? Millaisia eettisiä, sosiaalisi ja yksityisyyteen liittyviä kysymyksiä on ratkaistava, jos chatbot kyselee asiakkaalta myö henkilökohtaisia asioita luodakseen läheisem pää asiakassuhdetta?

Kansainvälisessä yritysten välisessä myynnissä digitalisoituminen, automatisoituminen ja robotiikan yleistyminen ovat jo muuttaneet myynnin käytäntöjä ja toimintamalleja (Syam \& Sharma 2018). Siksi on tutkittava, kuinka kansainvälinen B2B (business-to-business) myyntiprosessi ja vuorovaikutus myyntiprosessin aikana muuttuvat. Entä kuinka automatisoituminen ja robotiikka vaikuttavat johtamiseen? Työssäni olen saanut keskustella toimitusjoh tajien ja tiimipäälliköiden kanssa siitä, mit tapahtuu kun ihmisen ja robotin työ yhdistyy. Muutos on nykypäivän työyhteisöissä pysyvä olotila, mutta miten johtaa muutosta, ku kyse on ihmisen ja robotin työn yhdistelmästä? Kuinka työntekijät reagoivat siihen, että osan heidän työstään hoitaakin robotti ja miten se vaikuttaa esimerkiksi heidän työidentiteettiinsä (ks. Reissner, 2010)? Millaisia uusia teoreettisi näkökulmia vuorovaikutuksen tutkijat voisiva tuoda muutosjohtamiseen, kun kysymyksessä on ihmisen ja robotin yhteisen työn johtaminen muuttuvassa organisaatiossa?
Tämä on järjestyksessään neljästoista puheviesinnän vuosikirja ja se sisältää monipuolisia vuorovaikutukseen liittyviä tekstejä. Toimiuskunnalle tarjottiin yhteensä 11 artikkeliehdotusta ja yksi ehdotus kirja-arviosta. Näistä hyväksyimme jatkotyöstettäväksi 11. Toimitusunnalle palautui määräpäivään mennessä 8 käsikirjoitusta. Yksi näkökulma-artikkeli ei palautunut toimituskunnalle. Kaikki saapuneet käsikirjoitukset päätettiin lähettää vertaisarviointiin ja kaksi vertaisarvioijaa arvioi kunkin käsikirjoituksen. Vertaisarvioijat antoivat myönteisen signaalin 6 käsikirjoitukselle, joskin käsikirjoituksia tuli muokata palautteen perusteella. Toimituskunta oli vertaisarvioijien kanssa samaa mieltä ja edellytti, että lausunnoissa annetut parannusehdotukset huomioidaan käsikirjoituksen työstämisessä. Lopputuloksena on neljä vertaisarvioitua artikkelia. Lisäksi julkaistaan kirja-arvio ja kaksi väitöstilaisuuden lektiota.

Ensimmäisessä vertaisarvioidussa artikkelissa Suvi Lehtomäki ja Mirjamaija Mikkilä-Erdmann tutkivat opettajaa työrauhan rakentajana luokkavuorovaikutuksessa. Työrauhan rakentaminen kouluissa on tärkeä osa opettajan siantuntijuutta. Tässä tutkimuksessa kirjoittajat pyrkivät ymmärtämään, kuinka työrauha rakentuu opettajan ja oppilaiden välisessä vuorovaikutuksessa luokkahuoneessa. Tulokset 
osoittivat, että oppilaiden työrauhaa häiritsevää käyttäytymistä ilmeni suhteellisen usein, mutta häiriötilanteet olivat lieviä. Opettajat rakensivat työrauhaa luokissa monipuolisilla luokanhallintakeinoilla. Jatkossa olisi kuitenkin tutkittava, kuinka häiriötilanteiden toistuvuutta luokassa voitaisiin vähentää.

Toisessa vertaisarvioidussa artikkelissa Salli Hyttinen ja Tarja Valkonen tarkastelevat työikäisten aikuisten yksinäisyyttä tutkimuskohteena. Kyseessä on systemaattinen kirjal lisuuskatsaus, jossa jäsennetään ja arvioidaan, mitä tiedetään työikäisten (18-65 -vuotiaiden) aikuisten yksinäisyydestä. Tulokset osoittavat että viimeaikainen viestintätutkimus tähän teemaan liittyen on kohdistunut yksinäisten vuorovaikutussuhteiden rakentumiseen ja yksinäisten vuorovaikutuskäyttäytymiseen. Aikuisten yksinäisyyttä on tutkittu lähinnä kvantitatiivisin menetelmin ja yksinäisyyttä selittäviä tekijöitä on tutkittu pääosin introspektiivisin mittarein. Tutkimus on keskittynyt yliopisto-opiskelijoihin, joten tarvittaisiin tutkimusta myös muiden työelämässä olevien aikuisten yksinäisyydestä.

Kolmannessa artikkelissa Mia Scotson tutkii korkeakoulutettujen kotoutujien kielivalintoja vuorovaikutuskokemuksissa. Laadullisessa tutkimuksessa pyritään ymmärtämään, millaisi kielivalintoihin liittyviä positioita ilmenee korkeakoulutettujen kotoutujien kertomissa vuorovaikutuskokemuksissa ja mitkä tekijät vai kuttavat kielivalintoihin. Tulokset kertovat, etta tärkeimmät positiot olivat suomen kielen käyttäjä, englannin kielen käyttäjä ja suomenoppija. Positioihin vaikuttivat vuorovaikutuskumppanin toiminta sekä osallistujasta itsestään ja tilanteesta johtuvat tekijät. Tutkimus nostaa esiin puhekumppanin merkityksen vuorovaikutuksessa, kun puhuja harjoittelee suomen kieltä.
Neljännessä artikkelissa Maija Gerlander, Mikko Hautakangas ja Laura Ahva tutkivat vuorovaikutuksen jännitteitä toimittajan työssä. $\mathrm{He}$ ovat rajanneet näkökulmansa erityisesti sovittelujournalismiin. Vaikka toimittajan työtä on tutkittu runsaasti, vuorovaikutuksen tarkastelu toimittajan työssä on ollut vähäistä. Siksi tässä tutkimuksessa kirjoittajat analysoivat kuinka toimittajat kuvaavat työhönsä sisältyvää vuorovaikutusta ja siihen kuuluvia jännitteitä konflikteille alttiissa tilanteissa. Tuloksissa havaittiin neljä keskeistä jännitettä: vastakkainen a rinnakkainen orientaatio, ammatillinen ja henkilökohtainen identiteetti, tunteisiin liittyvä neutraalius ja ilmaiseminen sekä keskustelun seuraaminen ja aktiivinen ohjaaminen.

Vuonna 2018 Vuoden vuorovaikutusteko -kunniamaininnan sai Samu Kemppi. Hän on perustanut Instagramiin vertaistukea tarjoavan Apua nuorille -palvelun. Palvelu mahdollistaa supportiivisen vertaisvuorovaikutuksen ja pyrkii näin edistämään nuorten hyvinvointia.

Prologiin sisältyy kirja-arvio teoksesta Twitter viestintänä - Ilmiöt ja verkostot, jonka ovat toimittaneet Pekka Isotalus, Jari Jussila ja Janne Matikainen. Kirja-arvion on kirjoittanut professori Anu Sivunen. Väitöstilaisuuden lektion Prologissa julkaisevat Eveliina Pennanen ja Tomi Laapotti.

Lopuksi haluan kiittää toimituskunnan jäseniä suuresta työstä, jonka olette tämän vuoden vuosikirjan eteen tehneet. Lämpimät kiitokset teille Lotta Kokkonen, Emma Kostiainen ja Ira Virtanen. On ollut ilo työskennellä kanssanne nämä vuodet! Suuret kiitokset myös tämän vuoden vuosikirjaan tarjottujen käsikirjoitusten vertaisarvioijille.

Kuopiossa 24. marraskuuta 2018

Jonna Koponen

\section{Lähteet}

Arli, D., Bauer, C., \& Palmatier, R. W. 2018. Relation selling: Past, present and future. Industrial Marketing Management, 69, 169-184.

Atkinson, K. 2018. This robot co-taught a course at West Point. [viitattu 13.11.2018]. Saatavilla osoittees-teaching-collee-course-at-west-point-98ce5888-873b-4b72-8de5$0 \mathrm{c} 7 \mathrm{c} 592 \mathrm{~d} 66 \mathrm{~b} 0 \mathrm{html}$

Bodkin, H. 2017, Syyskuu 11. 'Inspirational robots to begin replacing teachers within 10 years. The Telegraph. [viitattu 13.11.2018]. Saatavilla osoitteessa: https://www.telegraph.co.uk

Chen, Y., Wang, Y., \& Chen, N. S. 2014. Is FLIP enough? Or should we use the FLIPPED model instead? Computers \& Education, 79, 16-27.

Edwards, A., Edwards, C., Spence, P., Harris, C., \& Gambino, A. 2016. Robots in the classroom: Differences in students' perceptions of credibility and learning between "teacher as robot" and "robot as teacher". Computers in Human Behavior, 65, 627634.

Edwards, A. \& Edwards, C. 2017. The machine are coming: future directions in instructiona communication research Communication Education, 66(4), 487-488

Edwards, C., Edwards, A., Spence, P. R. \& Lin, X 2018. I, teacher: using artificial intelligence (AI) and social robots in communication and instruction. Communication Education, 67(4), 473-480.

Hess, J. A. \& Mazer, J. P. 2017. Looking forward: envisioning the immediate future of instructiona communication research. Communication Education, 66(4), 474-499.

Hill, J., Ford, W.R. \& Farreras, I. G. 2015. Real conversations with artificial intelligence: A comparison between human-human onlin Computers in and hamantchat

Kantanen, H., Koponen, J., Sointu, E. \& Valtonen, T. 2018. Including student voice. Experiences an learning outcomes of a flipped organizational and marketing communication course. Konferenssiesitys 28.5.2018 International Communication Association, Praha, Tsekki.

Reissner, S. C. 2010. "Change, meaning and identity at the workplace", Journal of Organizational Change Management, 23(3), 287-299.
Syam, N. \& Sharma, A. 2018. Waiting for a sales renaissance in the fourth industrial revolution: Machine learning and artificial intelligence in sales esearch. Industrial Marketing Management, 69, 135-146.

Tusa, N., Sointu, E., Kastarinen, H., Valtonen, T., Kaasinen, A., Hirsto, L., Saarelainen, M., Mäkitalo, K. \& Mantyselka, P. 2018. Medical certificate lipped classroom. BMC Medical Eduction, 18:243. Valenzano III, J. M. \& Wallace, S. P. 2017. Expanding and exporting instructional communication scholarship: a necessary new direction. Communication Education, 66(4), 483-484. 